\title{
Impact of climate change on flood inundation in a tropical river basin in Indonesia
}

\author{
Kodai Yamamoto ${ }^{1}$, Takahiro Sayama ${ }^{2^{*}}$ (D) and Apip ${ }^{3}$
}

\begin{abstract}
Climate change will have a significant impact on the water cycle and will lead to severe environmental problems and disasters in humid tropical river basins. Examples include river basins in Sumatra Island, Indonesia, where the coastal lowland areas are mostly composed of peatland that is a wetland environment initially sustained by flooding from rivers. Climate change may alter the frequency and magnitude of flood inundation in these lowland areas, disturbing the peatland environment and its carbon dynamics and damaging agricultural plantations. Consequently, projecting the extent of inundation due to future flooding events is considered important for river basin management. Using dynamically downscaled climate data obtained by the Non-Hydrostatic Regional Climate Model (NHRCM), the Rainfall-Runoff-Inundation (RRI) model was applied to the Batanghari River Basin $\left(42,960 \mathrm{~km}^{2}\right)$ in Sumatra Island, Indonesia, to project the extent of flood inundation in the latter part of the twenty-first century. In order to obtain reasonable estimates of the extent of future flood inundation, this study compared two bias correction methods: a Quantile Mapping (QM) method and a combination of QM and Variance Scaling (VS) methods. The results showed that the bias correction obtained by the QM method improved the simulated flow duration curve (FDC) obtained from the RRI model, which facilitated comparison with the simulated FDC using reference rainfall data. However, the high spatial variability observed in daily and 15-day rainfall data remained as the spatial variation bias, and this could not be resolved by simple QM bias correction alone. Consequently, the simulated extreme variables, such as annual maximum flood inundation volume, were overestimated compared to the reference data. By introducing QM-VS bias correction, the cumulative density functions of annual maximum discharge and inundation volumes were improved. The findings also showed that flooding will increase in this region; for example, the flood inundation volume corresponding to a 20-year return period will increase by 3.3 times. River basin management measures, such as land use regulations for plantations and wetland conservation, should therefore consider increases in flood depth and area, the extents of which under a future climate scenario are presented in this study.
\end{abstract}

Keywords: Climate change, Flooding, NHRCM, Peatland, Quantile mapping, RRI model, Sumatra Island, The Batanghari River basin, Variance scaling

\footnotetext{
* Correspondence: sayama.takahiro.3u@kyoto-u.ac.jp

${ }^{2}$ Disaster Prevention Research Institute, Kyoto University, Gokasho, Uji, Japan

Full list of author information is available at the end of the article
}

\section{Springer Open}

(c) The Author(s). 2021 Open Access This article is licensed under a Creative Commons Attribution 4.0 International License, which permits use, sharing, adaptation, distribution and reproduction in any medium or format, as long as you give appropriate credit to the original author(s) and the source, provide a link to the Creative Commons licence, and indicate if changes were made. The images or other third party material in this article are included in the article's Creative Commons licence, unless indicated otherwise in a credit line to the material. If material is not included in the article's Creative Commons licence and your intended use is not permitted by statutory regulation or exceeds the permitted use, you will need to obtain permission directly from the copyright holder. To view a copy of this licence, visit http://creativecommons.org/licenses/by/4.0/. 


\section{Introduction}

Climate change will have a significant impact on waterrelated disasters and environmental problems in Indonesia. The country is one of the regions in which extreme monsoon-related rainfall is projected to increase (Hijioka et al. 2014), and such increases are expected to expose a larger proportion of the population to floods (Hirabayashi et al. 2013). In Sumatra and the Kalimantan Islands of Indonesia, coastal lowland areas are mostly comprised of peatland. Peatland is a wetland environment that is initially maintained by flooding from rivers and which has, in recent years, been extensively developed for oil palm and other plantations. Changes in the frequency and magnitude of flood inundation due to climate change may disturb the peatland environment and its carbon stores (Hirano et al. 2012), as well as cause damage to the agricultural plantations in the region.

The use of General Circulation Models (GCMs) is indispensable for projecting future climate change. However, GCMs have limitations in reproducing reasonable rainfall patterns in humid tropics, especially in areas with many islands such as those in the so-called Indonesian Maritime Continent (MC) (Ramage et al. 1968), which is surrounded by the Indian and Pacific oceans (Neale and Slingo 2003). These limitations can be attributed to the imperfect parameterization of physical processes (e.g., convection, cloud generation, local land sea breeze circulation, and regional variations in the diurnal cycle) (Gianotti et al. 2012; Ulate et al. 2014), as well as the coarse resolution of topography (Neale and Slingo 2003; Schiemann et al. 2014; Hertwig et al. 2015). Given the high levels of uncertainty associated with GCMs, they are considered to be poorly suited for projecting future climate signals in and around the MC (Hijioka et al. 2014). On the other hand, Regional Climate Models (RCMs) are capable of representing local climate systems and therefore have potential for realistically reproducing rainfall events. Several studies have shown that RCMs can successfully reproduce local rainfall patterns in space and time in the MC (Juneng et al. 2016; Cruz and Sasaki 2017; Rashid and Hirst 2017; Ratna et al. 2017; Kang et al. 2018).

Despite an abundance of studies on rainfall projections, studies on the impact of rainfall projections on river discharge are still limited in Indonesia (Emam et al. 2016; Marhaento et al. 2018). Moreover, very few studies have focused on flood inundation due to climate change at a river-basin scale, which is important for assessing the impacts on flood damage (Iwami et al. 2017) and wetland environmental conditions.

Even though RCMs are potentially better for hydrologic impact assessment in the $\mathrm{MC}$, there is still a need to correct the bias associated with RCMs (Christensen et al. 2008). Among the various bias correction methods
(Teutschbein and Seibert 2012), the Quantile Mapping (QM) method has been widely applied to correct rainfall inputs for hydrologic models (Huang et al. 2014; Marhaento et al. 2018; Lee et al. 2019). However, the applicability of the QM method to correct for bias in the $\mathrm{MC}$ region, particularly to assess flood inundation at the river-basin scale, has not been thoroughly investigated. Our previous study showed that inundation is more sensitive to rainfall than it is to runoff (Sayama et al. 2015). Therefore, it is important to investigate appropriate bias correction methods to assess the impact of flood inundation in a humid tropical river basin. Specifically, this study focuses on the effects of spatial variations of rainfall on flood inundation. The Variance Scaling (VS) method (Teutschbein and Seibert 2012) applied in this study is one of the potential approaches that can be used to match both the mean and the spatial variance of a data series with observed data.

The objective of this study was to assess the impact of climate change on flood inundation in a river basin on Sumatra Island. This study applied dynamically downscaled RCM rainfall data as the input for the RRI model and identified appropriate bias correction methods for flood simulations. The specific objectives are:

- What is the impact of non-/bias-corrected rainfall output of the RCM on river discharge and flood inundation?

- What is the most suitable method to correct rainfall bias when using the RCM to perform river discharge and inundation simulations?

- What are the projected future changes in rainfall, streamflow, and flood inundation in the studied region on Sumatra Island?

\section{Methods}

\subsection{Dataset}

This study uses climate data produced by the NonHydrostatic Regional Climate Model (NHRCM) that was developed by the Japan Meteorological Research Institute (MRI). The NHRCM is based on the NonHydrostatic Model (Saito et al. 2006), and the Kain and Fritsch scheme is used to parameterize cumulus convection (Kain and Fritsch 1993). The MRI-JMA Simple Biosphere Model is used to describe land surface processes (Hirai et al. 2007). The NHRCM uses a boundary condition of the Atmospheric General Circulation Model developed in ver. $3.2 \mathrm{~S}$ (AGCM) at a $20 \mathrm{~km}$ resolution (Mizuta et al. 2012) for downscaling to a $5 \mathrm{~km}$ resolution (Sasaki et al. 2008; Cruz and Sasaki 2017). The future boundary condition is based on changes of the CMIP3 ensemble mean sea surface temperature (SST) under the Representative Concentration Pathways 8.5 scenario (RCP8.5) (Endo et al. 2012). Downscaling 
was performed for our study area in Sumatra Island ($\left.3.32^{\circ} \mathrm{S}-0.41^{\circ} \mathrm{S} ; 99.65^{\circ} \mathrm{E}-105.25^{\circ} \mathrm{E}\right)$. The model is run for 21 years of present climate (1980-2000) and for 20 years of future climate (2079-2098) under the RCP8.5 scenario.

As reference rainfall data, this study uses Global Satellite Mapping of Precipitation (GSMaP) Reanalysis ver. 6 (Shimada and Kazumasa 2017) from 2001 to 2013 (13 years) with a resolution of $0.1^{\circ}$. The GSMaP Reanalysis product is satellite rainfall data that were calibrated using Japanese 55-year Reanalysis (JRA-55) data. In data-scarce regions such as the river basins of Sumatra Island, rain gauge data are typically too limited to accurately represent spatial patterns in rainfall data. Consequently, the availability of GSMaP data with a temporal resolution of $1 \mathrm{~h}$ on any grid is well suited for hydrologic modeling. However, it should be noted that the reference data also contain uncertainty. For example, compared with other reanalysis datasets, some issues have been identified in JRA-55 data over tropical regions, such as weaker equatorial waves and Madden-Julian oscillation due to the characteristics of the forecasting model used for JRA-55 with a resolution of $60 \mathrm{~km}$ (Harada et al. 2016). In this study, the quality of the GSMaP rainfall data is assessed based on gauged rainfall at 23 locations in the Batanghari River Basin.

The climatic data used for estimating evapotranspiration, such as wind speed, temperature, surface pressure, specific humidity, and downward long- and shortwave radiation fluxes, were obtained from WATCH Forcing Data based on ERA-Interim (Weedon et al. 2014) with a 0.5 -degree resolution. Land surface variables, such as the Leaf Area Index, surface roughness, and albedo, were obtained from ECOCLIMAP (Champeaux et al. 2005). Based on the data, potential evapotranspiration was estimated by using the Penman-Monteith equation to reference present climate conditions. The actual evapotranspiration is estimated by the RRI model, and the details are described in the "Rainfall-Runoff-Inundation Model" section.

\subsection{Bias correction and validation}

This study compares two methods to correct for bias in NHRCM rainfall data, i.e., the QM method and a combination of QM and VS methods (hereafter, the QM-VS method). The QM method used in this study employs equiratio cumulative distribution function (CDF) matching developed by Wang and Chen (2014). The method assumes that a ratio between the observed and modeled values at the same percentile is preserved in the projection period. Specifically, the bias between modeled and observed values in the reference period is quantified by the ratio of the observed quantile value $\left(F_{o-c}^{-1}\right)$ to the modeled quantile value $\left(F_{m-c}^{-1}\right)$ at the same percentile in a future projection period $\left(F_{m-p}\left(\overline{x_{m-p}}\right)\right)$. The statistical transformation of bias correction is shown in Eq. (1),

$$
x_{m-p . Q M .}^{i}=x_{m-p}^{i} \frac{F_{o-c}^{-1}\left(F_{m-p}\left(\overline{x_{m-p}}\right)\right)}{F_{m-c}^{-1}\left(F_{m-p}\left(\overline{x_{m-p}}\right)\right)}
$$

where $F_{m-p}$ is a CDF of RCM outputs in a future projection, $F_{o-c}^{-1}$ is an inverse CDF corresponding to the observations, $F_{m-c}^{-1}$ is an inverse CDF of RCM variables in the reference period, and $x_{m-p}^{i}$ is a quantile of a variable in a future projection at a grid $i . \overline{x_{m-p}}$ represents the spatial average over the basin of $x_{m-p}^{i}$. In this study, a CDF is constructed based on basin-averaged daily rainfall of observations and NHRCM data. The quantiles of the observation or model during the reference period at a given percentile of future rainfall are estimated by linear interpolation to compensate for differences in the size of the model and observation datasets.

The second method is a combination of the QM method and the VS method, which was described by Teutschbein and Seibert (2012). After calculating the differences in $x_{m-p . Q M .2}^{i}$ from the spatial mean $\overline{x_{m-p . Q M}}$ as shown in Eq. (2) on a daily basis, the VS method calculates the standard deviations of the spatial pattern $\sigma_{m-c}$. QM. $\mid j$ depending on the average rainfall categories represented as $j(j=1, \ldots, 21)$. Specifically, the categories include basin-averaged rainfall at a percentile $\left(\overline{x_{m-p . Q M}^{p e r}}\right)$ in an interval of five percentiles between 2.3 and 99 . Note that when $j$ equals 21 , the category includes rainfall exceeding $\overline{x_{m-p . Q M}^{99}}$. The spatial standard deviation is then adjusted according to Eq. (3), based on the spatial standard deviation of the observed rainfall $\left(\sigma_{o-c \mid j}\right)$ for each category. Finally, the corrected quantiles $x_{m-p \text {.QM.3 }}^{i}$ are shifted back to estimate the bias-corrected results

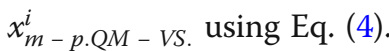

$$
\begin{aligned}
& x_{m-p . Q M .2}^{i}=x_{m-p . Q M .}^{i}-\overline{x_{m-p . Q M} .} \\
& x_{m-p . Q M .3}^{i}=x_{m-p . Q M .2}^{i} \frac{\sigma_{o-c \mid j}}{\sigma_{m-c . Q M . \mid j}}(j=1, \ldots, 21) \\
& x_{m-p . Q M-V S .}^{i}=x_{m-p . Q M .3}^{i}+\overline{x_{m}-p . Q M .}
\end{aligned}
$$

\subsection{Rainfall-runoff-inundation model}

The RRI model is a two-dimensional, distributed hydraulic and hydrological model that is capable of simulating rainfall-runoff and flood inundation simultaneously. The river channel is expressed as a single vector on a single grid cell, which also has a slope. Interaction between a river and the slope is calculated based on different overflowing 
formulae that vary according to levee height, river, and slope water depth. On a slope grid cell, the model can deal flexibly with rainfall-runoff processes and runoff-generation mechanisms, subsurface flow and saturated excess overland flow, vertical infiltration and excess overland flow, and complete surface flow. In addition, groundwater flow can be combined with subsurface flow and vertical infiltration processes (Sayama et al. 2012). In the RRI model, actual evapotranspiration is calculated by first subtracting surface water, before subtracting additional water from a cumulative infiltration amount estimated by the Green-Ampt model until it meets the potential evapotranspiration. When the value approaches 0 , there is no water to evaporate and actual evapotranspiration at that time is less than the potential evapotranspiration.

\subsection{Study area and application of the RRI model}

The Batanghari River Basin is the second largest river basin in Indonesia $\left(42,960 \mathrm{~km}^{2}\right)$ (Fig. 1a). The river originates in the Barisan Mountains before merging with the Tembesi River as it runs eastward towards the coast. Downstream, the river is diverted into the Kumpeh River and merged again. At Simpang, the river is diverged into the Berbak River (Fig. 1b).

The climate is classified as humid tropical, and monthly rainfall typically exceeds $100 \mathrm{~mm}$ (Chang and Lau 1993). The average air temperature is within the range of $22.2 \pm 0.2^{\circ} \mathrm{C}$ (upstream) and $26.8 \pm 0.2^{\circ} \mathrm{C}$ (downstream) based on climate stations maintained by the Indonesian Agency for Meteorological, Climatological and Geophysics (BMKG) from 2001 to 2013

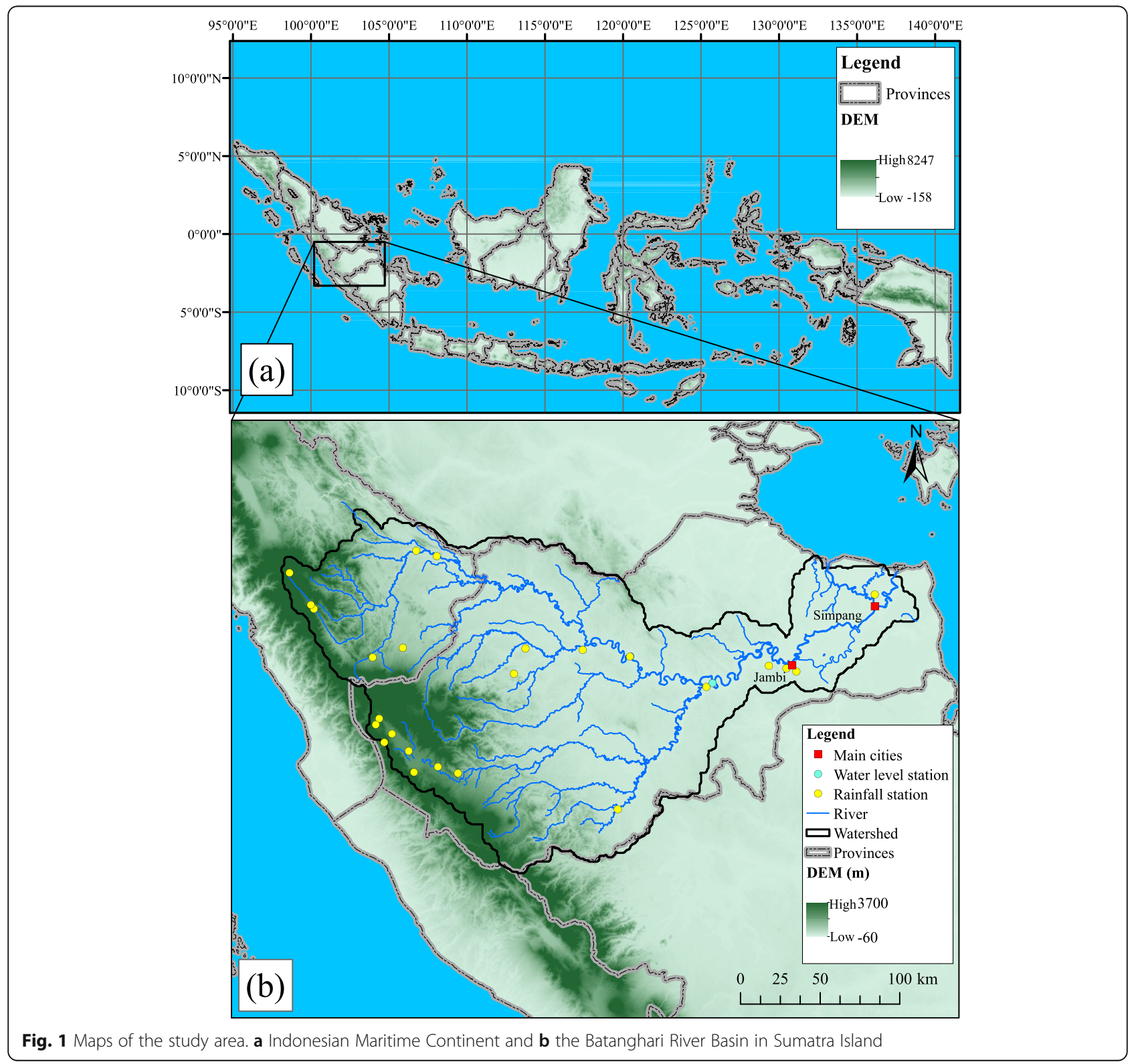


(Yamamoto et al. 2020). Despite high monthly rainfall, there is a distinct wet season and dry season that is strongly influenced by two monsoons. The wet monsoon originates in the northern hemisphere and causes rainfall to increase from November to March, and the dry monsoon originates in the southern hemisphere and causes a decrease in rainfall from May to September. The wet monsoon has two clear peaks: one in December and another in April (bimodal rainfall). In the wet season, fluvial flooding can occur in the Batanghari River Basin. In some extreme cases, these floods can affect Jambi city located in the downstream river reaches.

The topography of the area is comprised of mountains that range in height from 1000 to $3700 \mathrm{~m}$ in the upstream river reaches, and wetlands in the low-lying flat areas. Forest soils are thick, typically deeper than $1.5 \mathrm{~m}$ on mountainous slopes, and have high infiltration rates. Tropical peatlands occur along the eastern coast of $\mathrm{Su}$ matra Island.

For the application of the RRI model, Manning's roughness for river and land were set to $0.03 \mathrm{~m}^{-1 / 3} \mathrm{~s}$ and $0.3 \mathrm{~m}^{-1 / 3} \mathrm{~s}$, respectively, based on a previous study (Sayama et al. 2012). The soil depth and parameters of the groundwater model, which affect discharge, were adjusted for the calibration period (2001-2006) and used for the validation period (2007-2013). The details of the model parameters and model set up were the same as those of Yamamoto et al. (2019). The performance of the RRI model with GSMaP Reanalysis rainfall input was evaluated based on observed river discharge for the calibration period and the validation period. In addition, the maximum inundation distribution was estimated for 4 months (December 2016 to March 2017) using the RRI model. The estimates were compared with sentinel satellite images from four flood events (December 6, 2016, and January 23, February 27, and March 24, 2017). The sentinel images were developed using the radar reflection intensity before and after flooding, and the maximum extent of flood inundation during these periods was estimated for comparison with our simulations.

\section{Results}

3.1 Comparison of annual and 15-day rainfall patterns and basin-averaged values estimated using the NHRCM with GSMaP data and gauged data

We compared the spatial distribution patterns of annual rainfall (Fig. 2) and annual maximum 15-day rainfall (Fig. 3) estimated using the NHRCM with reference rainfall data (i.e., GSMaP and gauged data). Figure 2a shows that the GSMaP data indicate high annual rainfall in the northern mountainous ranges of the basin, which corresponds with the gauged rainfall data. The detailed values for the gauged rainfall data and the gridded GSMaP rainfall data are shown in Figure S1 and Table S1. Figure $2 \mathrm{a}$ also shows that the rainfall patterns in the basin have a diagonal pattern that is parallel with the mountain ranges in the western part of the basin. We can visually distinguish that the rainfall in the basin is divided into several parts, i.e., the mountainous region, the central region, the area next to Jambi city (the narrowest part of the basin), and the coastal region. The NHRCM data shown in Fig. $2 \mathrm{~b}$, in general, also show a similar division of rainfall patterns. Based on the reference rainfall data, rainfall was high in the northern part of the mountain ranges and low in the central part of the mountain ranges. The NHRCM data show consistently lower rainfall in the mountainous areas. The rainfall of the reference data is relatively high in the center of the basin, decreasing towards the west. The rainfall decreases near Jambi city before increasing towards the coastal region. These rainfall patterns can also be observed in the NHRCM data, although the rainfall is higher in the central and eastern parts of the basin (approximately 3500 to $7500 \mathrm{~mm}$ ) compared to the reference data, as shown by the dark gray areas in Fig. 2b. Moreover, the NHRCM data show higher spatial variability in annual rainfall compared to the reference data. Figure 3a shows a comparison of the annual maximum 15-day rainfall GSMaP data with gauged data. On the one hand, the GSMaP data have a similar 15-day rainfall pattern as the gauged data in the mountainous regions, the southwestern part of the basin, and

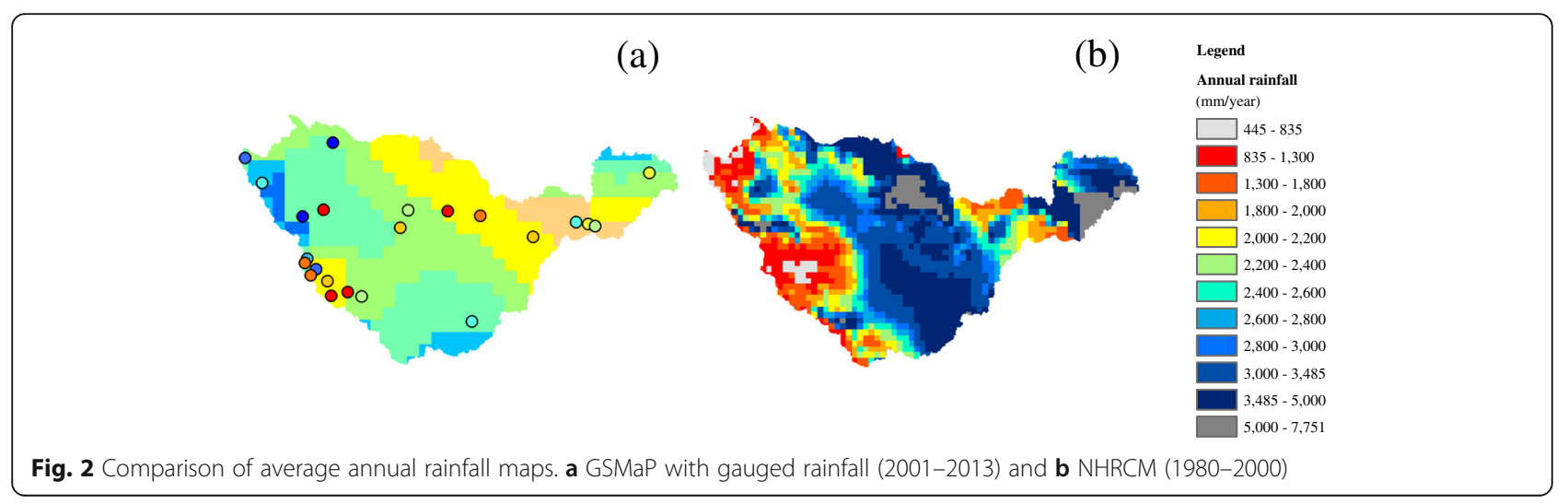




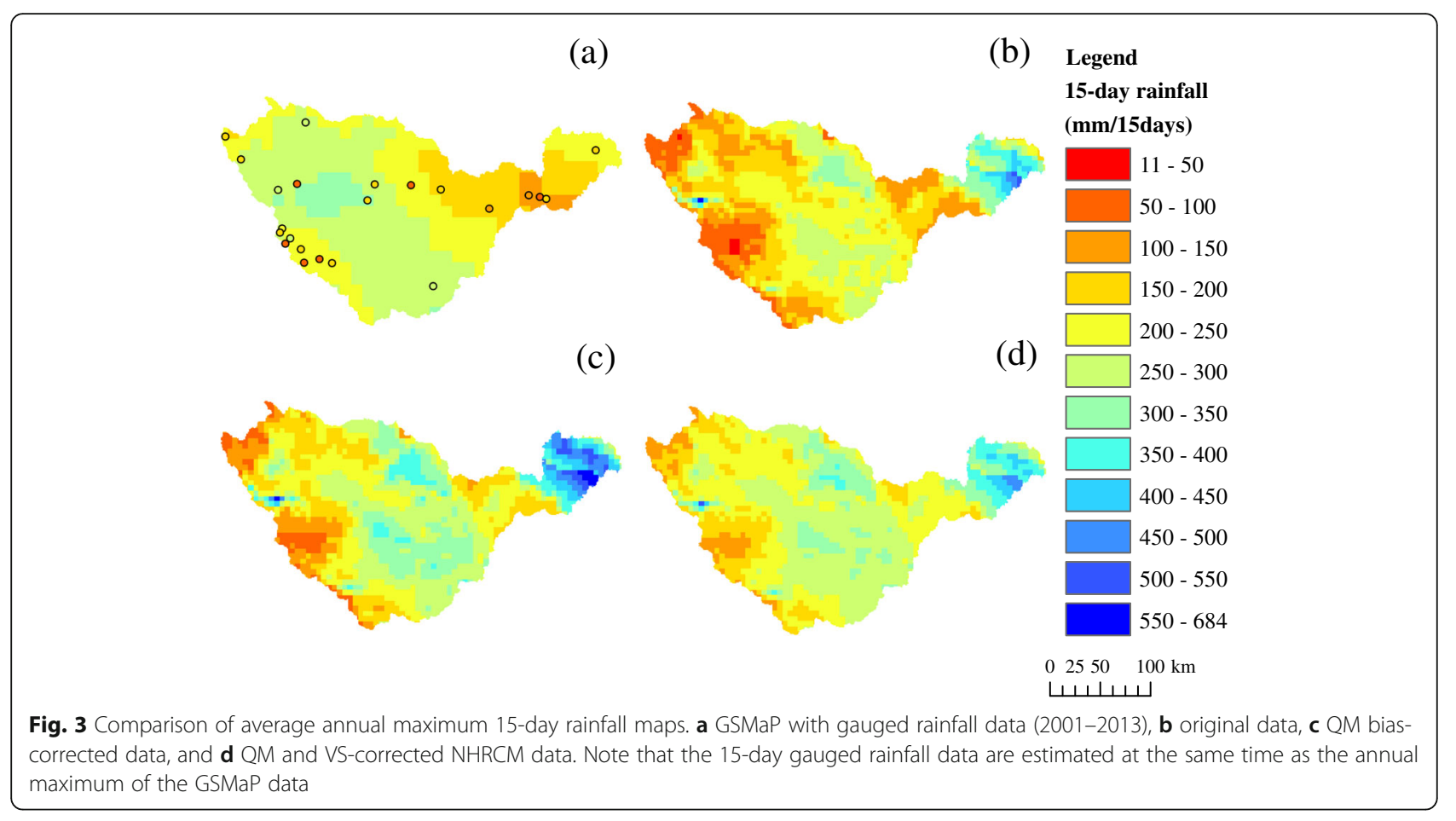

downstream areas, such as the area around Jambi city and the coastal area. On the other hand, the GSMaP data tend to show higher rainfall in some parts of mountainous regions in the western part of the basin. The detailed values of gauged rainfall and the gridded rainfall of the GSMaP are shown in Figure S2 and Table S2. Figure 3b shows that NHRCM data also have higher spatial variability in terms of annual maximum 15-day rainfall compared to reference data (Fig. 3a), and it also has higher rainfall amounts (about 350 to 552 $\mathrm{mm}$ ) in areas such as the lowland areas.

We also compared basin-averaged values of the NHRCM and the reference rainfall data with the gauged data. The average annual rainfall over the basin was estimated to be $2321 \mathrm{~mm}$ by GSMaP and $2021 \mathrm{~mm}$ by the rain gauges (Yamamoto et al. 2019). The basin-averaged annual rainfall values of the NHRCM are higher than those of the reference rainfall data, which was $2913 \mathrm{~mm}$. Figure 4 shows a comparison of the CDFs of annual maximum daily and 15-day rainfall of raw and QM bias-corrected NHRC $\mathrm{M}$ and GSMaP data. The annual maximum basinaveraged daily rainfall of NHRCM data (average 29 $\mathrm{mm}$ ) is lower than that of GSMaP data (average 51 $\mathrm{mm}$ ) (Fig. 4a). Figure 4b also compares the annual maximum 15-day rainfall (basin average)-cumulative rainfall which is strongly correlated with peak discharge. NHRCM data generally have a lower annual maximum 15-day rainfall (average $206 \mathrm{~mm}$ ) compared to GSMaP data (average $242 \mathrm{~mm}$ ).

\subsection{Effects of bias corrections (QM and QM-VS) on rainfall}

In this study, we compared two bias correction methods, i.e., the QM method and the QM-VS method. The annual basin average rainfall was improved from 2913 to $2316 \mathrm{~mm}$ by using the QM method and to $2328 \mathrm{~mm}$ by using the QM-VS method, which is closer to the GSMaP value $(2321 \mathrm{~mm})$. The findings of this study also show that both methods result in similar CDFs for the annual maximum daily and 15-day rainfall, as shown in Fig. 4.

Despite the similar results in the corrected basin average values, the application of both methods gives different results in the spatial variability of annual rainfall and annual maximum 15-day rainfall. The application of the QM method lowers the spatial variability of annual rainfall, but does not improve the variability for the annual maximum 15-day rainfall. Figure 3c shows the results of the QM method after it was applied to the spatial variability observed in the annual maximum 15-day rainfall data. Some areas, including the central parts of the basin and the mountainous areas, showed that rainfall is corrected within the range of 250 to $400 \mathrm{~mm}$, which more closely reflects the reference data (about 150 to 333 $\mathrm{mm}$ ). However, the rainfall values obtained in the lowland areas showed much higher values, ranging from 350 to $600 \mathrm{~mm}$ compared with the reference data (about 140 to $250 \mathrm{~mm}$ ). On the other hand, the application of the QM-VS method results in a lower spatial variability for both annual rainfall and annual maximum 15-day rainfall. Figure $3 \mathrm{~d}$ shows the bias correction results obtained using the QM-VS method, which typically has 

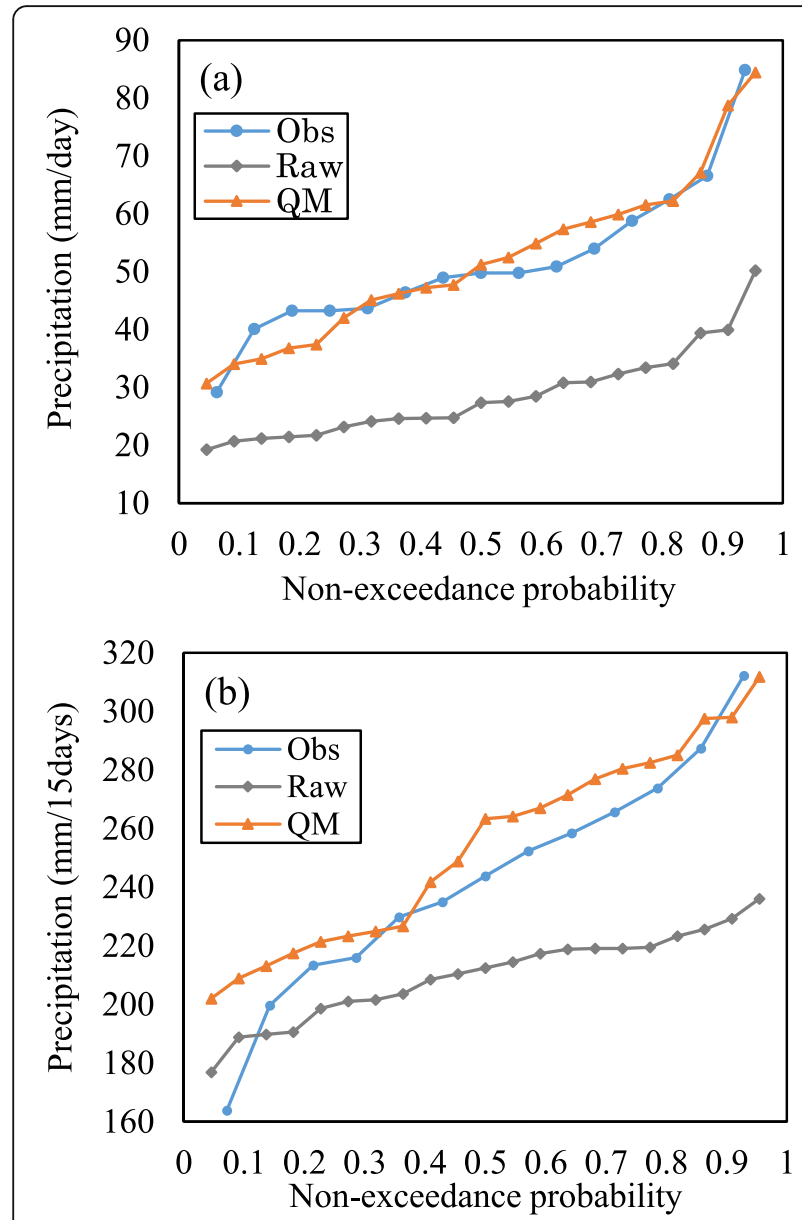

Fig. 4 Comparison of CDFs of annual maximum cumulative rainfall for different durations. a Daily and $\mathbf{b}$ 15-day rainfall of raw data, QM bias-corrected NHRCM and GSMaP data

lower spatial variability than the corrections obtained using the QM method. Unlike the results obtained using the QM method, the rainfall values observed in the lowland areas are closer to those of GSMaP. The improvement in spatial variability due to bias correction is confirmed by Fig. 5, which shows the relationship between spatially averaged daily rainfall and the corresponding spatial standard deviations over the basin. The original NHRCM data have higher spatial standard deviations compared with the GSMaP data (Fig. 5a1). The application of the QM method results in higher standard deviations, particularly at high rainfall rates (Fig. 5a2); conversely, the application of the QM-VS method successfully improved the standard deviations, making them comparable with the standard deviations obtained using GSMaP (Fig. 5a3).

\subsection{Effects of bias corrections on the RRI simulation}

The calibration and validation results of the RRI model are shown in Fig. 6, which shows a comparison of the
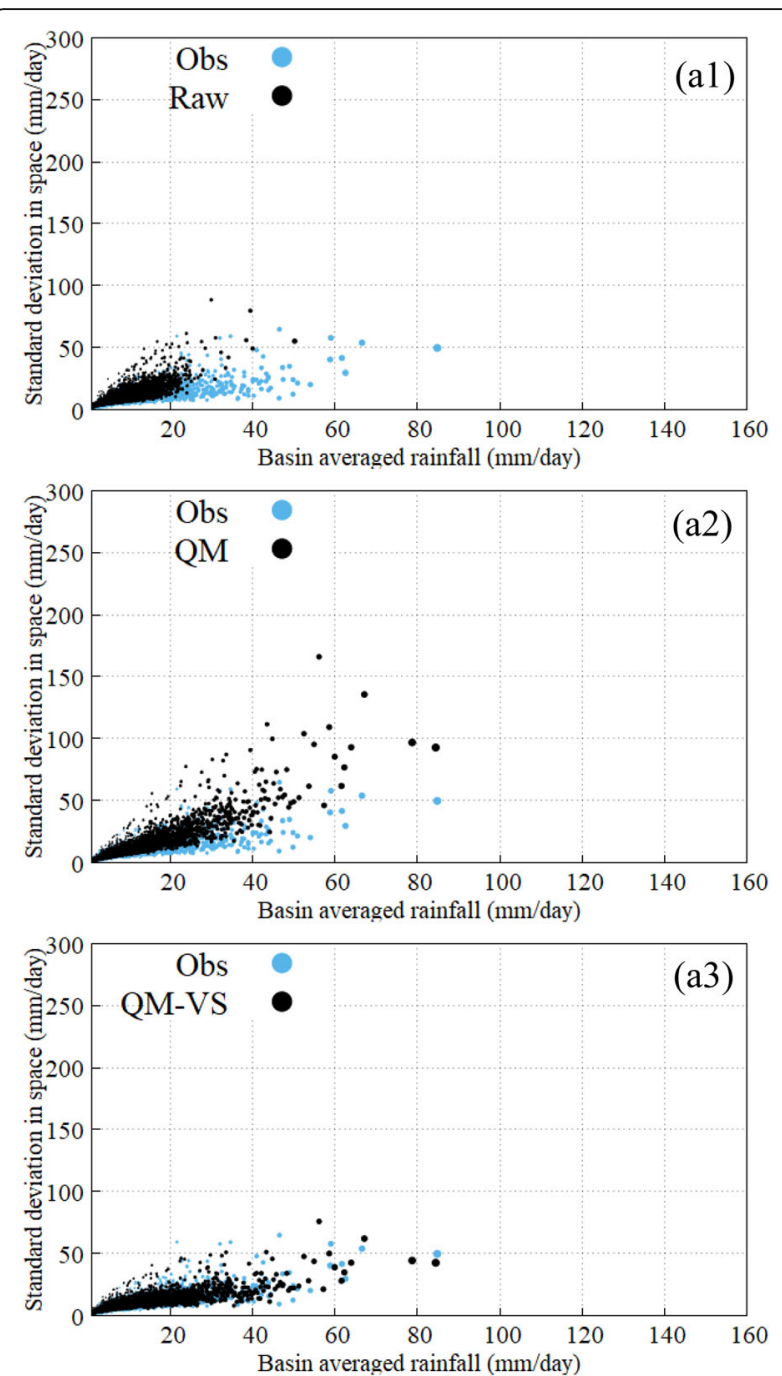

Fig. 5 Scatter diagram of basin-averaged daily rainfall and corresponding standard deviations in space of a1 raw NHRCM data, QM bias-corrected a2 NHRCM data, and QM and VS bias-corrected a3 NHRCM data

simulated and observed monthly river discharges. The model performance is considered satisfactory (Moriasi et al. 2007) in that the Nash-Sutcliffe efficiency (NSE) is 0.57 in the calibration period (2001-2006) and 0.51 in the validation period (2007-2013). To validate the simulated inundation patterns, we compared the maximum inundation distribution from December 2016 to March 2017 using the maximum flood extent inferred by sentinel satellite imagery (Fig. 7a). The simulated inundation pattern (Fig. 7b) agrees well with the satellite image of the Batanghari River and its tributaries.

Figure 8 shows the simulated flow duration curves (FDCs), annual maximum discharge, and inundation volume estimated using the original NHRCM, GSMaP, and bias-corrected rainfall data. For the reference discharge and inundation volume (referred to as observed (Obs) in Fig. 8), we use the GSMaP rainfall data as the input for 


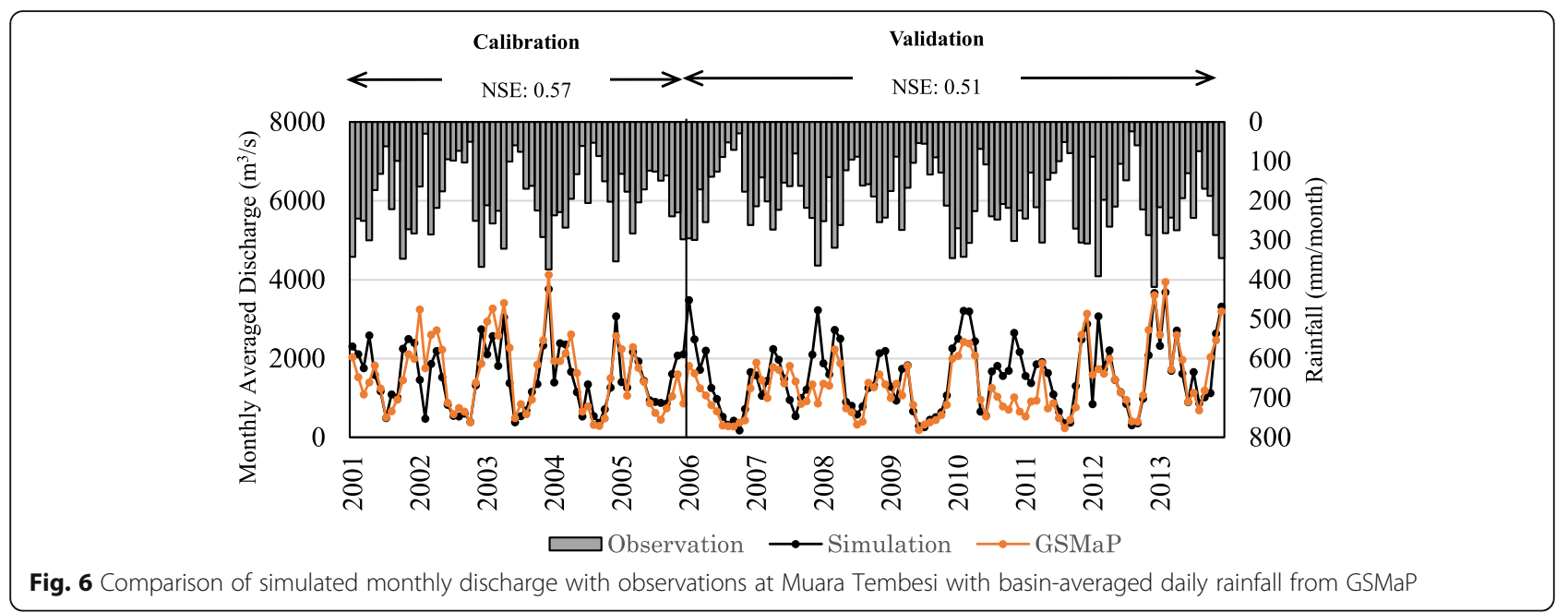

the simulation. The simulated FDC obtained using the original NHRCM data shows that medium flows $\left(\mathrm{Q}_{20}\right.$ to $\left.\mathrm{Q}_{60}\right)$ and low flows $\left(\mathrm{Q}_{70}\right.$ to $\left.\mathrm{Q}_{99}\right)$ are overestimated, and high flows $\left(\mathrm{Q}_{0.1}\right.$ to $\left.\mathrm{Q}_{10}\right)$ are underestimated (Fig. 8a); the ranges of high, medium, and low flows are defined based on Mohamoud (2008).

Table 1 summarizes the evaluation scores obtained for the annual maximum discharge (Fig. 8b) and inundation volume (Fig. 8c) simulated by raw/bias-corrected NHRC $M$ rainfall data based on relative root mean square error (RRMSE) and relative mean error (RME). For annual maximum discharges, Table 1 shows that the QM method had nearly the same accuracy, in terms of the RRMSE (0.11), as the original NHRCM. However, compared to the raw data, the accuracy of the QM method was lower for estimating annual maximum inundation

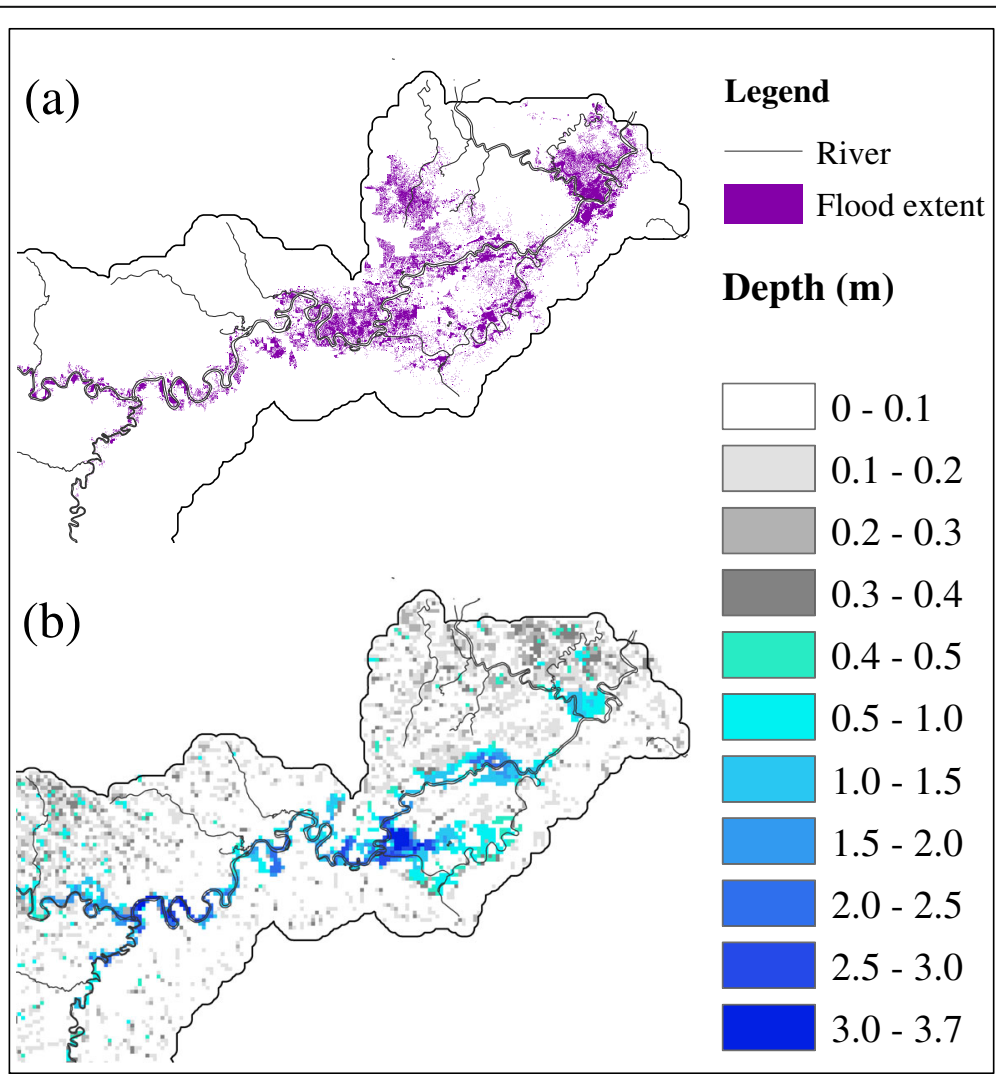

Fig. 7 Observation-based and simulated flood inundation maps for the downstream area. a Maximum flood extent captured by sentinel satellite and $\mathbf{b}$ simulated maximum inundation depth distribution with GSMaP Reanalysis 

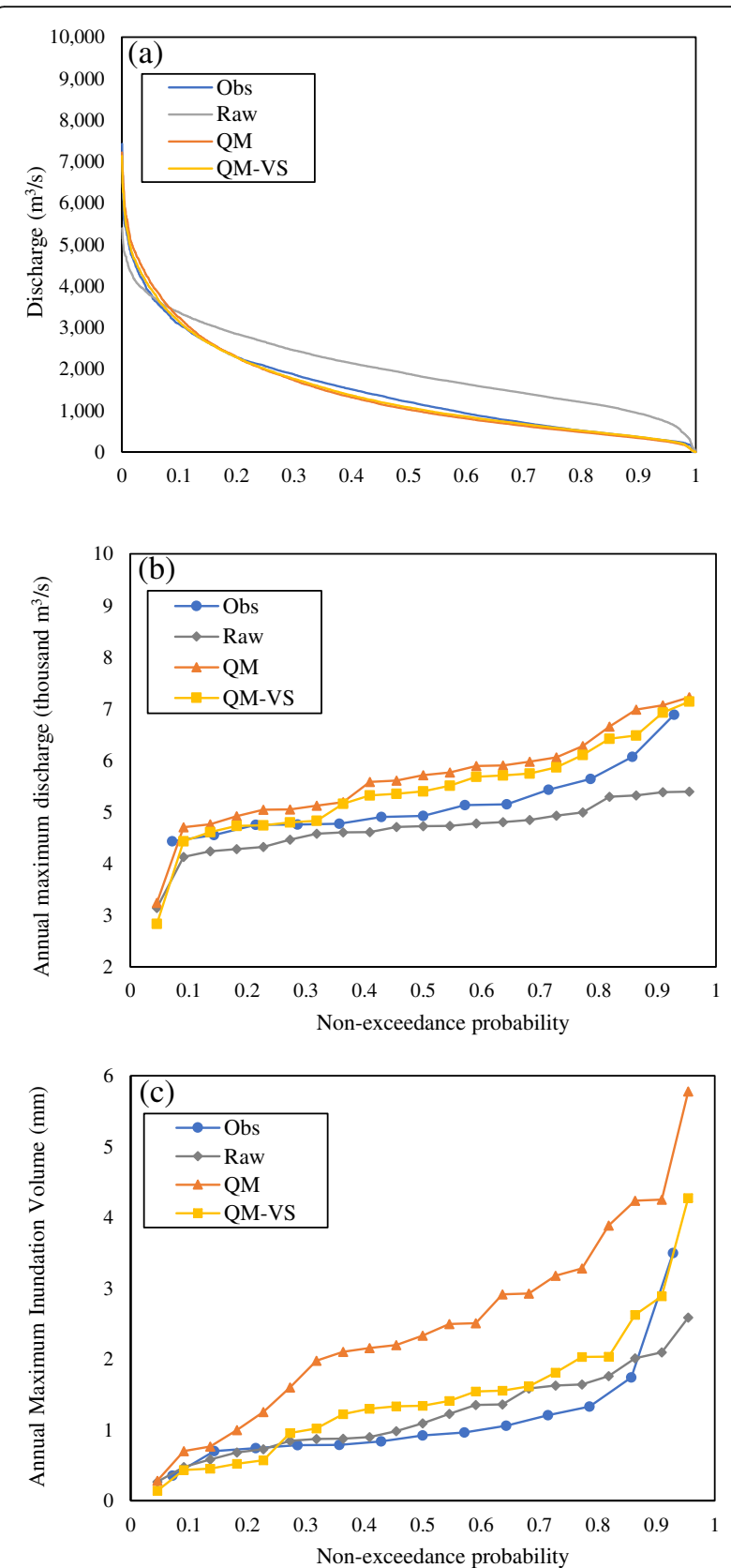

Fig. 8 Effects of bias corrections on hydrological variables. Comparison of $\mathbf{a}$ FDCs, $\mathbf{b}$ CDFs of annual maximum discharge, and $\mathbf{c}$ CDFs of annual maximum inundation volume of raw data, QM and QM-VS bias-corrected NHRCM data, and GSMaP data volumes. We confirmed that the application of the QM and VS bias correction method improved the RRMSE (0.39) and RME (0.37) compared to the RRMSE (1.06) and RME (1.13) obtained using the QM method alone.

\subsection{Projection of rainfall, discharge, and inundation under future climate conditions}

Figure 9 shows the change in annual rainfall patterns between the present and future climate conditions. In general, annual rainfall will increase throughout the basin. In some areas, including the central or lower parts of the basin, the projected increase in annual rainfall is more than $650 \mathrm{~mm}$. Figure 10 shows that the annual maximum daily and 15-day rainfall will also increase for all return periods. For example, annual maximum daily rainfall corresponding to a 20 -year return period (i.e., non-exceedance probability equals 0.05 ) will increase from 84 to $276 \mathrm{~mm}$ (Fig. 10a), and the corresponding increase in annual maximum 15-day rainfall will be from 350 to $666 \mathrm{~mm}$ (Fig. 10b).

Figure 11 shows the FDC and basin-averaged annual maximum inundation volume under present and future climate conditions. The range of the FDC will increase under future climate conditions (Fig. 11a). In particular, the medium flow in the future climate is $2035 \mathrm{~m}^{3} / \mathrm{s}$, which is a $42 \%$ increase compared to the present climate. Future flood inundation volume will increase for all return periods (Fig. 11b). For example, flood inundation volume in the future climate corresponding to a 20year return period is $14.2 \mathrm{~mm}$, which is an increase of 3.3 times compared to the present $(4.3 \mathrm{~mm})$. Annual maximum inundation distributions under future climate conditions (Fig. 12b) show that flood depth reaches a maximum of $4.8 \mathrm{~m}$, and the total inundated area increases by 2.3 times, compared to that of the present climate (Fig. 12a). Most of the lowland areas are exposed to flooding and flood depth ranges within $0.4 \mathrm{~m}$ and 4.8 $\mathrm{m}$.

\section{Discussion}

4.1 Effects of bias corrections on precipitation, river discharge, and inundation volume

In terms of annual rainfall, the NHRCM rainfall data for the Batanghari River Basin are higher than the reference rainfall data (GSMaP and gauged data). In the same

Table 1 Evaluation of annual peak discharges and annual maximum inundation volume with a raw/bias-corrected NHRCM against those with GSMaP

\begin{tabular}{lll}
\hline Bias correction method & Annual peak discharge & Annual maximum inundation volume \\
\hline Raw & RRMSE 0.11, RME - 0.094 & RRMSE 0.35, RME 0.048 \\
QM & RRMSE 0.11, RME 0.093 & RRMSE 1.06, RME 1.13 \\
QM-VS & RRMSE 0.079, RME 0.047 & RRMSE 0.39, RME 0.37
\end{tabular}

The notations of bias corrections are "Raw" for non-bias correction, "QM" for Quantile Mapping, and "QM-VS" for Quantile Mapping and Variance Scaling. The shows relative root mean square error (RMSE) and relative mean error (RME) 


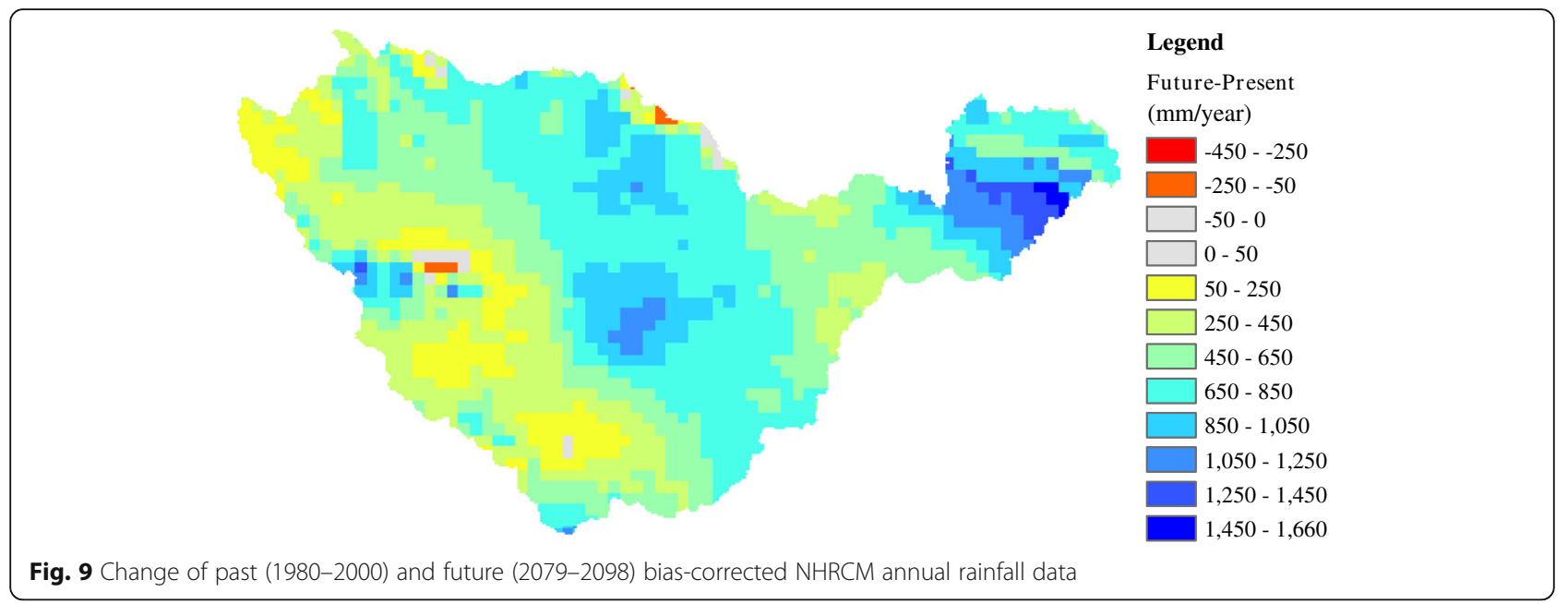

target river basin, three RCMs from BMKG also overestimated annual rainfall (Handoko et al. 2019). This wet bias may be caused by the boundary conditions associated with dynamical downscaling (Gianotti et al. 2012; Cruz et al. 2016).

As in the reference data, the NHRCM (Fig. 2b) shows similar differences in the rainfall patterns that developed parallel to the mountain range (Fig. 2a). We find that this is also true for the annual maximum 15-day rainfall of the NHRCM (Fig. 3b). However, differences between the NHRCM and reference rainfall data were also observed. In the reference rainfall data, rainfall was high only in the northern parts of the mountain ranges, but it was low in the central parts of the mountains. On the other hand, the NHRCM rainfall data showed that rainfall was consistently lower in the mountainous areas. In addition, the NHRCM rainfall data showed that rainfall in the central and eastern parts of the basin was higher than that measured using the reference data. Compared to early GCM outputs, the representation of topography and dynamical downscaling have improved the spatial and temporal resolution of rainfall maps in recent years (Schiemann et al. 2014; Johnson et al. 2015). However, our analysis shows that NHRCM exhibits high spatial variability in both annual rainfall and extreme rainfall data. This variability may be attributed to the rainshadow effect, i.e., rainfall is reduced on the leeward side of a mountain and increased on the windward side (Chang et al. 2005). Previous studies on the NHRCM also reported that this effect may explain some of the rainfall variability observed in the NHRCM data (KieuThi et al. 2016; Cruz and Sasaki 2017). The high variability of NHRCM data may also be one of the reasons for the slightly higher annual maximum inundation volume, which can be affected by spatially and temporally concentrated rainfall (Sayama et al. 2015).

Both of the bias correction methods resulted in similar improvements for basin-averaged rainfall values (annual,
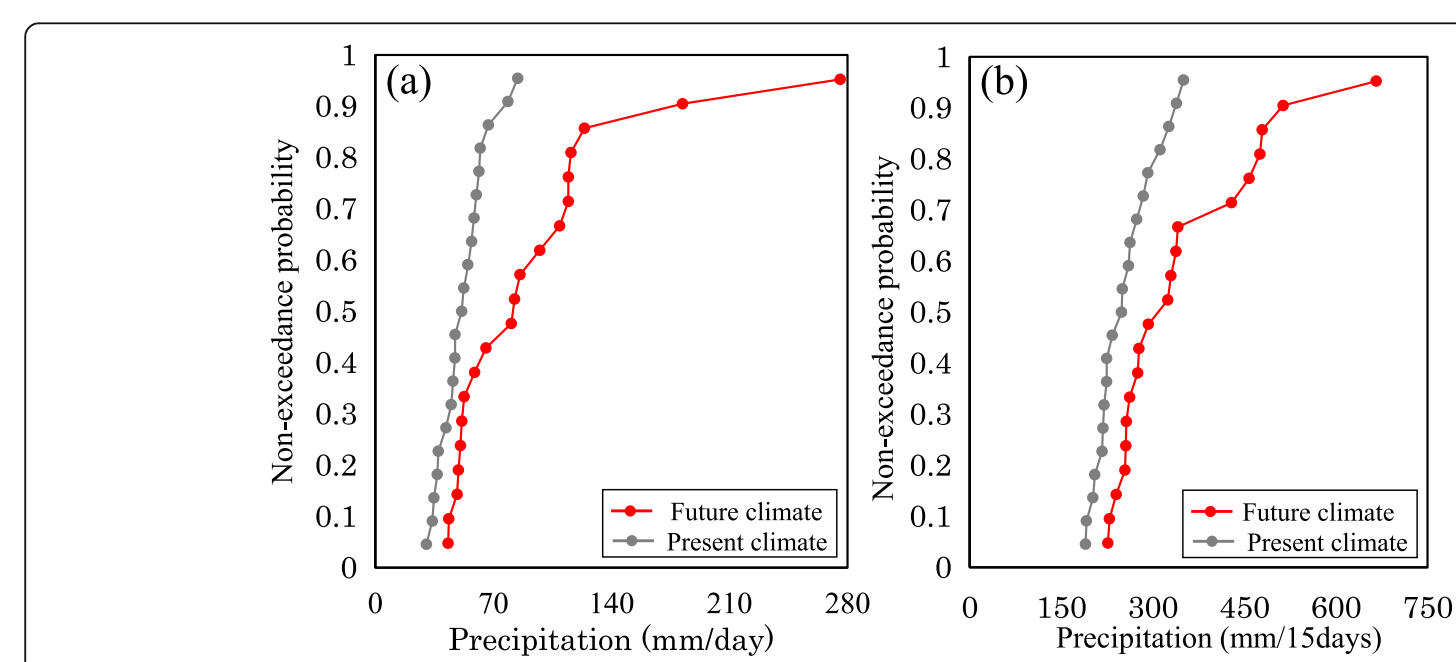

Fig. 10 Projected CDF of present and future NHRCM annual maximum a daily and $\mathbf{b}$ 15-day rainfall data 

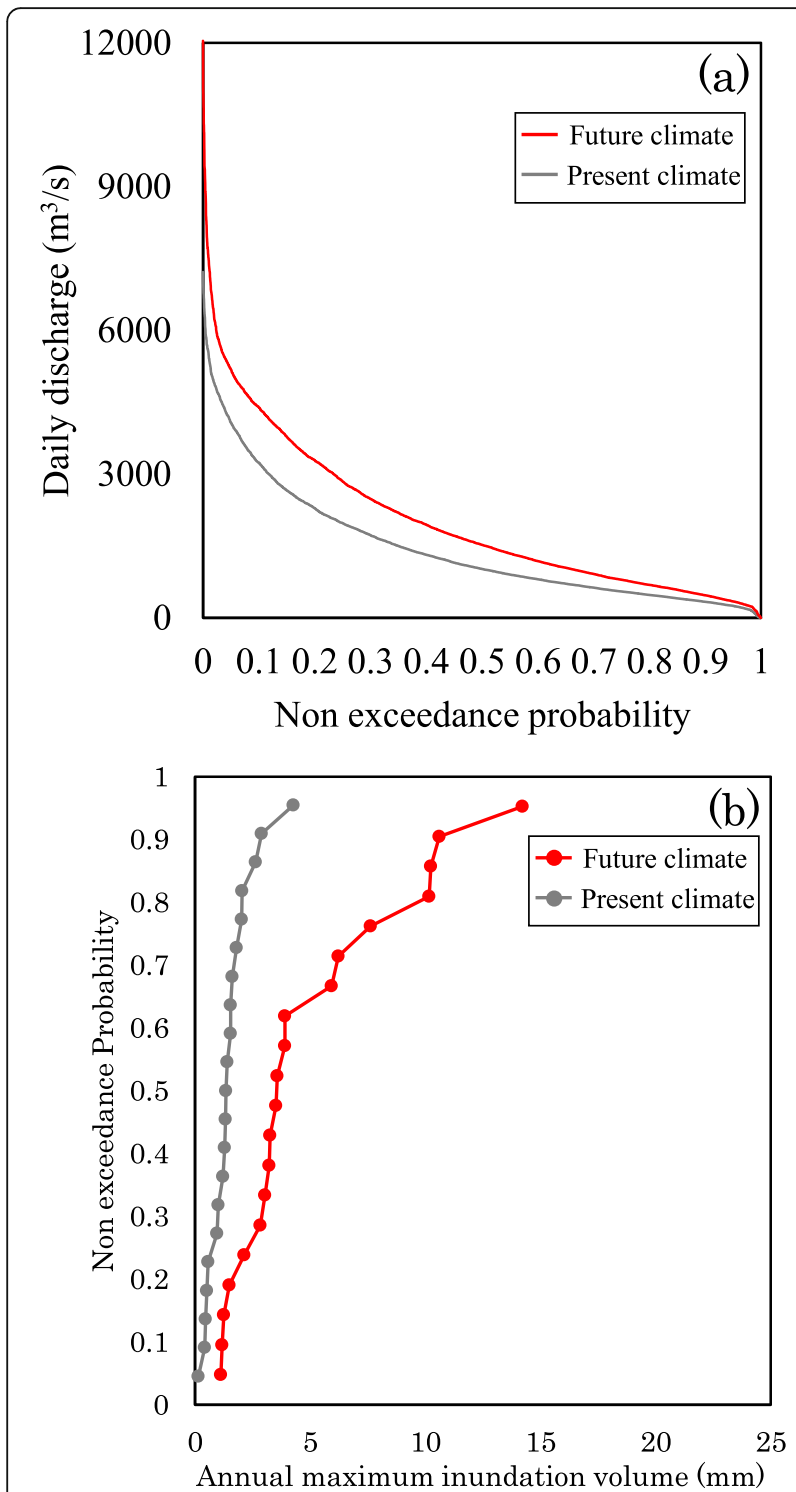

Fig. 11 Hydrological variables of bias-corrected present and future data. a Flow duration curve and $\mathbf{b}$ CDFs of annual maximum inundation volume

annual maximum daily, and annual maximum 15 days), which is expected because the additional VS method does not change the average values, only the variance over space. While the two methods reduced the spatial variability of annual rainfall, they differed in the spatial variability of the annual maximum 15-day rainfall; the QM method increased the spatial variability, while the QM-VS method decreased it. The use of equiratio cumulative distribution function matching, as described in the "Methods" section, may explain why the spatial variability increases after the application of the QM method. Unlike the typical use case of the QM method, which matches the CDF at a grid scale, this study matches the $\mathrm{CDF}$ of basin-averaged rainfall values to preserve the spatial pattern of the NHRCM. Nevertheless, the variability observed in the raw NHRCM data changes after multiplying the ratio uniformly by all rainfall values in the basin; when the ratio $<1$, the variability is reduced, and when it is $>1$, the variability is increased. When the basin-averaged value is more than about $12 \mathrm{~mm}$, the ratio is more than 1 . The annual 15-day rainfall data are mostly a series of high rainfall values with a ratio $>1$, which causes the high variability. The additional variance-scaling step in the QM-VS method matches the variance with the reference data, reducing the high variability through application of the equiratio CDF matching.

We also investigated the impact of the bias correction methods on hydrologic simulations. The simulation using the QM bias-corrected rainfall data improved the FDC, as has been demonstrated by several hydrological impact studies that used QM bias-corrected GCM or RCM rainfall as an input for their hydrologic models (Teutschbein and Seibert 2012; Huang et al. 2014; Lee et al. 2019). However, the simulation using QM bias-corrected rainfall leads to overestimation of extreme variables (annual maximum discharge and annual maximum inundation volume). This may be caused by the higher variability of rainfall. On the other hand, QM-VS bias correction improved basin average and spatial variabilities of the annual maximum 15day rainfall, producing reasonable extreme variables over the target river basin.

Although correction of basin-averaged rainfall is not typical, it is considered rational for river discharge simulations. According to Beven and Hornberger (1982), assessing the correct volume of rainfall input from a highly spatially variable pattern is considerably more important than a rainfall spatial pattern in predicting storm flow hydrographs. However, bias correction methods that match the CDF of basin-averaged rainfall with equiratio CDF matching may lead to higher spatial variability, particularly for extreme values; therefore, correcting the variance over the space improves the results.

\subsection{Projection of rainfall, discharge, and inundation under future climate conditions}

The strongest and most consistent increase in seasonal rainfall broadly follows the Inter Tropical Convergence Zone, which lies above southern Indonesia in December, January, and February and northern Indonesia in June, July, and August (Christensen et al. 2007). A recent study showed that RCMs, dynamically downscaled from three GCMs over the Western Maritime Continent, consistently projected an increase in rainfall in December, January, and February under RCP4.5 and RCP8.5 scenarios in parts of Sumatra Island, and a significant decrease in rainfall during inter-monsoon seasons (Kang et al. 2018). 


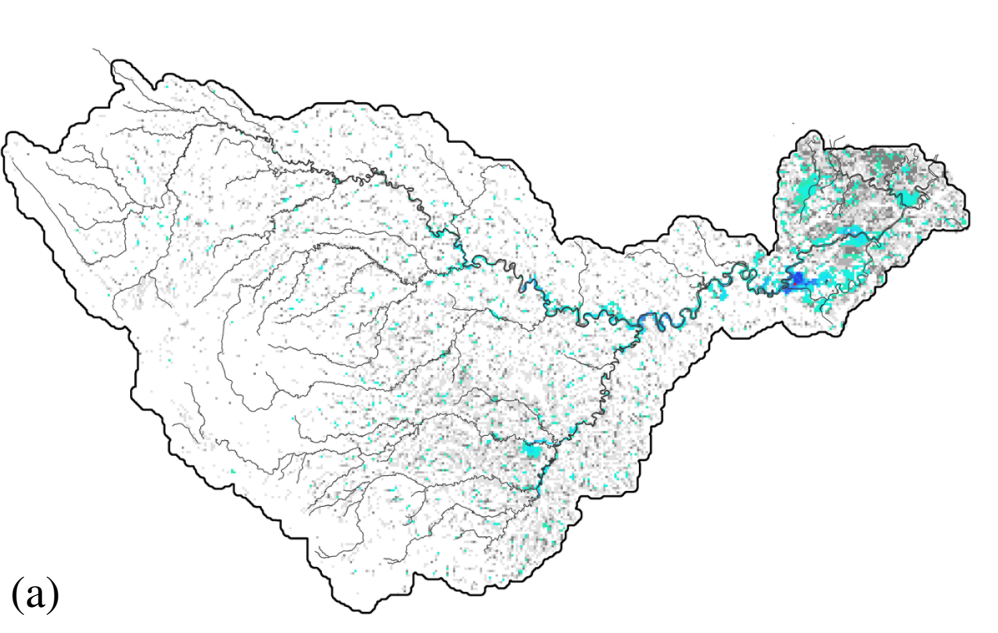

Depth (m)
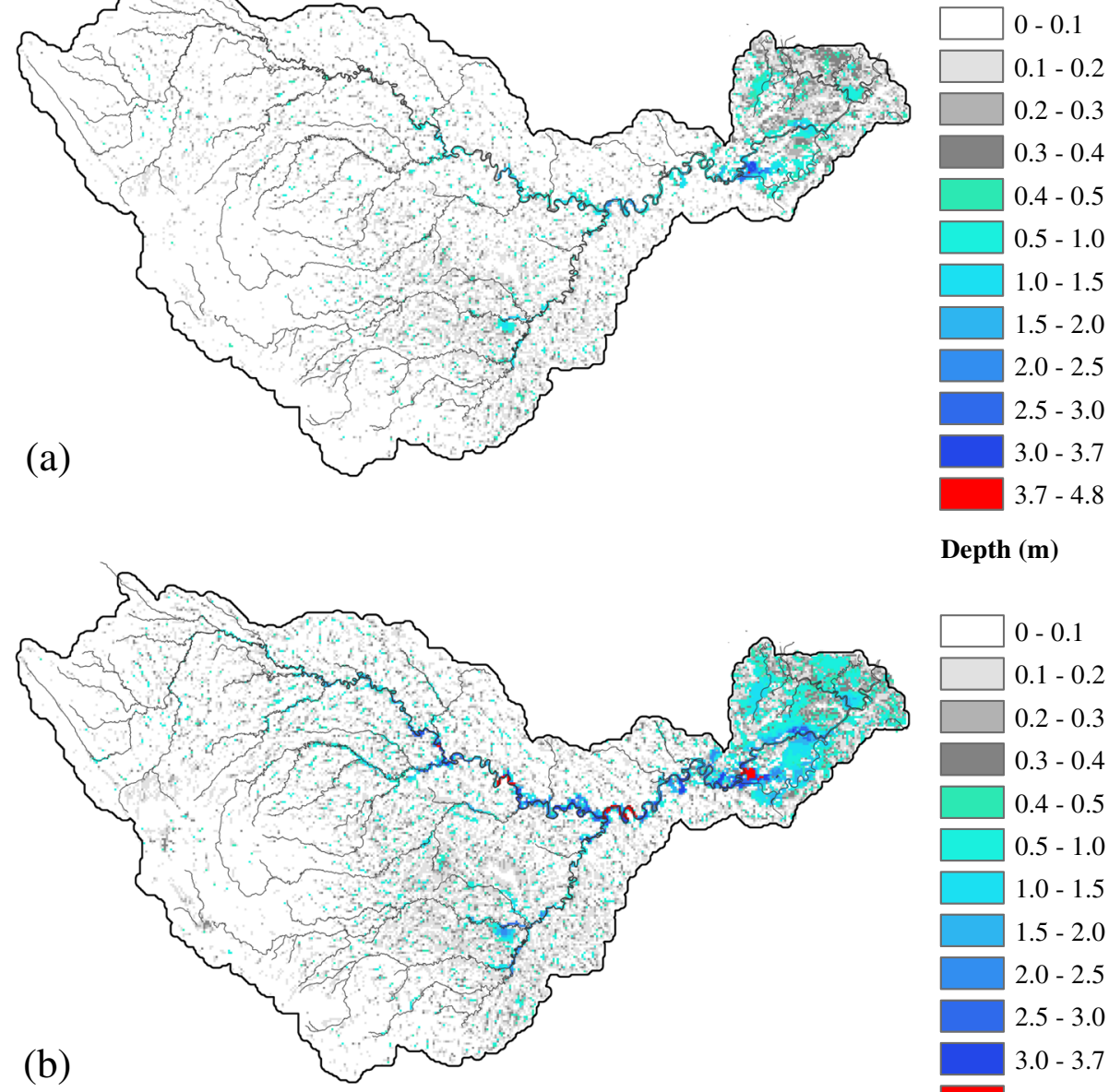

Depth (m)

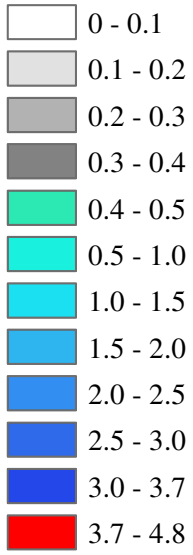

Fig. 12 Projection of NHRCM annual maximum inundation depth distribution $\mathbf{a}$ under present and $\mathbf{b}$ in future climate conditions

In this study, the annual maximum 15-day rainfall intensity was projected to increase in the Batanghari River Basin under RCP8.5 in the late twenty-first century. This agrees with IPCC AR5, which reports that the frequency and intensity of extreme rainfall will likely increase over wet tropical regions in the late twenty-first century (Stocker et al. 2013). Collins et al. (2013) also showed that in most parts of Sumatra Island, the annual maximum 5day rainfall increased by more than $20 \%$ in the late twenty-first century under RCP8.5 scenarios. In addition, extreme events, such as 100-year annual maximum daily rainfall, will occur more frequently in the late twenty-first century under RCP8.5 scenarios (Stocker et al. 2013). The findings of this and previous study (Muis et al. 2015) show that the annual maximum inundation volume is projected to increase in the Batanghari River Basin under RCP8.5 in the late twenty-first century. Based on Muis et al. (2015), using the global flood model combined with scenarios of 5 GCMs with 4 RCPs also projects an increase in inundation volumes with a 100-year return period in parts of Sumatra Island; however, there is considerable uncertainty across the projections for the Indonesian region. Our results suggested that frequent expansion of the flood inundation area in the downstream area of the basin will damage agricultural crops. According to a global data projection by Fujimori et al. (2018), in one of the Shared Socioeconomic Pathways (SSP) (Popp et al. 2017), particularly SSP3, cropland area in the Batanghari River Basin will increase continuously until 2100. Without implementing any adaptation measures, the lowland areas of Sumatra Island are likely to become more agriculturally developed due to the large potential of unused areas, such as peatlands. The findings suggest that the river basin should be managed by implementing adaptation measures, such as land use regulation of plantations, promoting wetland conservation in order to prevent damage due to flooding under future climate conditions, and protecting the unique environments of tropical peatland areas. 


\subsection{Limitations of the research}

In some regions of Asia, shallow orographic rainfall occurs by low-level orographic lifting of maritime air leading to heavy rainfall (Shige et al. 2013; Shige and Kummerow 2016). In humid areas that experience tropical rainfall caused by these shallow orographic rain systems, original satellite rainfall products tend to perform poorly because they employ microwave radar algorithms (Kubota et al. 2007; Shige et al. 2013). To overcome the issue, the ability to distinguish between orographic and non-orographic rainfall systems has been developed and implemented in the GSMaP algorithm ver. 6 (Shige et al. 2013; Yamamoto and Shige 2015). Furthermore, for the GSMaP Reanalysis data, the wind dataset from JRA-55 is used to detect orographic rainfall. Nevertheless, according to Nodzu et al. (2019), who assessed rainfall in areas with very complex topography (including several mountainous ranges) in northern Vietnam, some bias remains in GSMaP Reanalysis ver. 6; specifically, they observed higher (lower) rainfall on the leeward (windward) side of mountains in their case study. In our study, the coverage of the gauged data is still not sufficient to accurately assess the characteristics and potential biases of the GSMaP product. With the limited data, the annual rainfall and 15-day rainfall were overestimated, particularly in the leeward side of the Barisan Mountains. These uncertainties in the reference data may affect the model calibration and other parts of our study.

It is essential that climate change impact studies evaluate the uncertainty of future climate change impacts by comparing results with/without dynamical downscaling using different RCP/SST scenarios and GCMs/RCMs. In this study, a dynamically downscaled product of AGCM under one SST scenario was used due to limitations imposed by computational resources and to retain the focus of this paper on bias correction methods. As for the effects of different SST scenarios, we ran the RRI model based on the original AGCM outputs without dynamical downscaling. Figure S3 shows that the increasing rates of flood inundation volume range from 1.9 to 4.8 times without downscaling. Although the result of 3.3 times based on the downscaling was within the range, we realize that there are large uncertainties and that these are dependent upon SST patterns. In a future study, it will be necessary to conduct more downscaling experiments with different SST patterns.

To focus on the flood analysis, this study did not consider future temperature changes in the Batanghari River Basin. However, changes in temperature can increase evapotranspiration, which can dry the land and promote fires (Takahashi et al. 2003). According to the NHRCM, the average monthly surface temperature (basin average) increases by $3{ }^{\circ} \mathrm{C}$ in any season in the Batanghari River
Basin (see Figure S4 showing the basin-averaged monthly temperature for present and future simulations using the original NHRCM). In order to assess the impact on the tropical peatland environment, it is necessary to use future temperature as an input for the hydrologic model.

\section{Conclusions}

This study compared the two bias correction methods, i.e., the QM method and a combination of the QM and VS methods, to examine how each method improves estimates of rainfall patterns and subsequently the simulated flood inundation by the RRI model in the Batanghari River Basin, Indonesia. Originally, the dynamically downscaled NHRCM rainfall data showed higher spatial variation in the 15-day rainfall and annual rainfall compared to the reference data. While this does not markedly influence the simulated FDC, it largely overestimated the extreme values, such as the annual maximum flood inundation volume. The combination of QM and VS methods successfully decreased the rainfall spatial variability and improved the estimations of the FDCs and the extreme values.

Our analysis showed that the projected change of flood inundation is significant, particularly in the lowland areas of Sumatra Island. Annual maximum flood inundation volume corresponding to a 20-year return period would increase by 3.3 times. The annual maximum inundation map under a future climate scenario showed that the inundation depths would increase and the inundated area would expand in tropical peatland areas. These results suggest the need to consider future climate change scenarios for river basin management, particularly to reduce the risk of flood damage and to sustainably maintain the unique ecosystem of tropical peatlands.

\section{Supplementary Information}

The online version contains supplementary material available at https://doi. org/10.1186/s40645-020-00386-4.

Additional file 1: Table S1. Comparison between annual rainfall values of gauged rainfall and gridded rainfall from GSMaP.

Additional file 2: Table S2. Comparison between 15-day rainfall values of gauged rainfall and annual maximum 15-day rainfall of gridded rainfall from GSMaP.

Additional file 3: Figure S1. Identical to Figure 2a, but the station numbers are shown.

Additional file 4: Figure S2. Identical to Figure 3a, but the station numbers are shown.

Additional file 5: Figure S3. Projected CDFs of annual maximum inundation volume based on present and future AGCM data with four SST clusters (CO, C1, C2 and C3).

Additional file 6: Figure S4. Monthly average surface temperatures (basin average) under present climate (1980-2000) and future climate (2079-2098) conditions projected by NHRCM. 


\section{Abbreviations}

AGCM: Atmospheric General Circulation Model developed by the Japan Meteorological Research Institute ver. 3.2S; BMKG: Indonesian Agency for Meteorological, Climatological and Geophysics; CDF: Cumulative Distribution Function; FDC: Flow Duration Curve; GCMs: General Circulation Models; GSMaP: Global Satellite Mapping of Precipitation; JRA-55: The Japanese 55year Reanalysis; MC: Maritime Continent; NHRCM: Non-Hydrostatic Regional Climate Model; NSE: Nash-Sutcliffe Efficiency; QM: Quantile Mapping method; RCMs: Regional Climate Models; RRI: Rainfall-Runoff-Inundation; SSP: Shared Socioeconomic Pathways; SST: Sea Surface Temperature; VS: Variance Scaling

\section{Acknowledgements}

We thank Dr. Hidetaka Sasaki at the Japan Meteorological Research Institute for providing a downscaled dataset of the NHRCM. We also appreciate the assistance of The TOUGOU project members, particularly Prof. Eiichi Nakakita and Prof. Yasuto Tachikawa at Kyoto University, for supervising the research project in Indonesia.

\section{Authors' contributions}

$\mathrm{KY}$ analyzed the data and performed numerical simulations. TS designed the study and led the project. AA supported the field work and data collection. The authors have read and approved the final manuscript.

\section{Funding}

This work was supported by the Integrated Research Program for Advancing Climate Models (TOUGOU) Project (Theme D: PI: EN), JSPS KAKENHI Grant Number 17 H04586 (PI: TS), and JST Japan-ASEAN Science, Technology and Innovation Platform (JASTIP) (PI: YK, Leader of WP4: KT).

\section{Availability of data and materials}

The datasets supporting the conclusions of this article are currently not available in any public repository. However, data are available from the corresponding author upon reasonable request.

\section{Competing interests}

The authors declare that they have no competing interests.

\section{Author details}

${ }^{1}$ Graduate School of Engineering, Kyoto University, Nishigyo Ward, Kyoto, Japan. ${ }^{2}$ Disaster Prevention Research Institute, Kyoto University, Gokasho, Uji, Japan. ${ }^{3}$ Research Center for Limnology, Indonesian Institute of Sciences (LIPI), Jalan Raya Jakarta-Bogor Km 46, Cibinong, Bogor 16911, Indonesia.

Received: 3 March 2020 Accepted: 31 October 2020

Published online: 06 January 2021

\section{References}

Beven KJ, Hornberger GM (1982) Assessing the effect of spatial pattern of precipitation in modeling stream flow hydrographs. J Am Water Resour Assoc 18(5):823-829

Champeaux JL, Masson V, Chauvin F (2005) ECOCLIMAP: a global database of land surface parameters at $1 \mathrm{~km}$ resolution. Meteorol Appl 12(1):29-32. https://doi.org/10.1017/S1350482705001519

Chang CP, Wang Z, Mcbride J, Liu CH (2005) Annual cycle of Southeast Asia-Maritime Continent rainfall and the asymmetric monsoon transition. J Climate 18:287-301. https://doi.org/10.1175/JCLI-3257.1

Chang JH, Lau LS (1993) A definition of the humid tropics. In: Bonell M, Hufschmidt MM, Gladwell JS (eds) Hydrology and water management in the humid tropics: hydrological research issues and strategies for water management. Cambridge University Press, UNESCO, Cambridge, pp 571-574

Christensen JH, Boberg F, Christensen OB, Lucas-Picher P (2008) On the need for bias correction of regional climate change projections of temperature and precipitation. Geophys Res Lett 35(20):L20709. https://doi.org/10.1029/ 2008GL035694

Christensen JH, Hewitson B, Busuioc A, Chen A, Gao X, Held I, Jones R, Kolli RK, Kwon W-T, Laprise R, Magaña Rueda V, Mearns L, Menéndez CG, Räisänen J, Rinke A, Sarr A, Whetton P (2007) Regional climate projections. In: Solomon S, Qin D, Manning M, Chen Z, Marquis M, Averyt KB, Tignor M, Miller HL (eds) Climate change 2007: the physical science basis. Contribution of Working Group I to the Fourth Assessment Report of the Intergovernmental Panel on Climate Change. Cambridge University Press, Cambridge and New York
Collins M, Knutti R, Arblaster J, Dufresne JL, Fichefet T, Friedlingstein P, Gao X, Gutowski WJ, Johns T, Krinner G, Shongwe M, Tebaldi C, Weaver AJ, Wehner M (2013) Long-term climate change: projections, commitments and irreversibility. In: Stocker TF, Qin D, Plattner G-K, Tignor MMB, Allen SK, Boschung J, Nauels A, Xia Y, Bex V, Midgley PM (eds) Climate change 2013: the physical science basis. Contribution of Working Group I to the Fifth Assessment Report of the Intergovernmental Panel on Climate Change. Cambridge University Press, Cambridge and New York

Cruz FT, Sasaki H (2017) Simulation of present climate over Southeast Asia using the non-hydrostatic regional climate model. SOLA 13:13-18. https://doi.org/ 10.2151/sola.2017-003

Cruz FT, Sasaki H, Narisma GT (2016) Assessing the sensitivity of the nonhydrostatic regional climate model to boundary conditions and convective schemes over the Philippines. J Meteorol Soc Jpn 94(A):165-179. https://doi. org/10.2151/jmsj.2015-059

Emam AR, Mishra BK, Kumar P, Masago Y, Fukushi K (2016) Impact assessment of climate and land-use changes on flooding behavior in the upper Ciliwung River, Jakarta, Indonesia. MDPI Water 8(12):559. https://doi.org/10.3390/ w8120559

Endo H, Kitoh A, Ose T, Mizuta R, Kusunoki S (2012) Future changes and uncertainties in Asian precipitation simulated by multiphysics and multi-sea surface temperature ensemble experiments with high-resolution Meteorological Research Institute atmospheric general circulation models (MRI-AGCMs). J Geophys Res 117:D16118. https://doi.org/10.1029/ 2012JD017874

Fujimori S, Hasegawa T, Ito A, Takahashi K, Masui T (2018) Gridded emissions and land-use data for 2005-2100 under diverse socioeconomic and climate mitigation scenarios. Sci Data 5:13. https://doi.org/10.1038/sdata.2018.210

Gianotti RL, Zhang D, Eltahir EAB (2012) Assessment of the regional climate model version 3 over the maritime continent using different cumulus parameterization and land surface schemes. J Climate 25:638-656. https:// doi.org/10.1175/JCLI-D-11-00025.1

Handoko U, Boer R, Aldrian E, Latifah AL, Dasanto BD, Apip A, Misnawati M (2019) Comparison performance of the multi-Regional Climate Model (RCM) in simulating rainfall and air temperature in Batanghari watershed. Aceh Int J Sci Technol 8(2):52-67. https://doi.org/10.13170/aijst.8.2.12340

Harada Y, Kamahori H, Kobayashi C, Endo H, Kobayashi S, Ota Y, Onda H, Onogi K, Miyaoka K, Takahashi K (2016) The JRA-55 reanalysis: representation of atmospheric circulation and climate variability. J Meteor Soc Japan 94:269302. https://doi.org/10.2151/jmsj.2016-015

Hertwig E, Storch JSV, Handorf D, Dethloff K, Fast I, Krismer T (2015) Effect of horizontal resolution on ECHAM6-AMIP performance. Climate Dynam 45: 185-211. https://doi.org/10.1007/s00382-014-2396-x

Hijioka Y, Lin E, Pereira JJ, Corlett RT, Cui X, Insarov GE, Lasco R, Lindgren E, Surjan A (2014) Asia. In: Barros VR, Field CB, Dokken DJ, Mastrandrea MD, Mach KJ, Bilir TE, Chatterjee M, Ebi KL, Estrada YO, Genova RC, Girma B, Kissel ES, Levy AN, MacCracken S, Mastrandrea PR, White LL (eds) Climate change 2014: impacts, adaptation, and vulnerability. Part B: regional aspects. Contribution of Working Group II to the Fifth Assessment Report of the Intergovernmental Panel on Climate Change. Cambridge University Press, Cambridge and New York, pp 1327-1370

Hirabayashi Y, Mahendran R, Koirala S, Konoshima L, Yamazaki D, Watanabe S, Kim H, Kanae S (2013) Global flood risk under climate change. Nature Clim Change 3:816-821. https://doi.org/10.1038/nclimate1911

Hirai M, Sakashita T, Kitagawa H, Tsuyuki T (2007) Development and validation of a new land surface model for JMA's operational global model using the CEOP observation dataset. J Meteor Soc Japan 85:1-24. https://doi.org/10. 2151/jmsj.85A.1

Hirano T, Segah H, Kusin K, Limin S, Takahashi H, Osaki M (2012) Effects of disturbances on the carbon balance of tropical peat swamp forests. Glob Chang Biol 18(11):3410-3422. https://doi.org/10.1111/j.1365-2486.2012.02793.x

Huang S, Krysanova V, Hattermann FF (2014) Does bias correction increase reliability of flood projections under climate change? A case study of large rivers in Germany. Int J Climatol 34:3780-3800. https://doi.org/10.1002/joc.3945

Iwami Y, Hasegawa A, Miyamoto M, Kudo S, Yamazaki Y, Ushiyama T, Koike T (2017) Comparative study on climate change impact on precipitation and floods in the Asian river basins. Hydrol Res Lett 11(1):24-30. https://doi.org/ 10.3178/hrl.11.24

Johnson SJ, Levine RC, Turner AG, Martin GM, Woolnough SJ, Schiemann R, Mizielinski MS, Roberts MJ, Vidale PL, Demory ME, Strachan J (2015) The resolution sensitivity of the South Asian monsoon and Indo-Pacific in a 
global 0.35AGCM. Climate Dynam 46:807-831. https://doi.org/10.1007/ s00382-015-2614-1

Juneng L, Tangan F, Chung JX, Ngai ST, Tay TW, Narisma G, Cruz F, Phan-Van T, Ngo-Duc T, Santisirisomboon J, Singhruck P, Gunawan D, Aldrian E (2016) Sensitivity of Southeast Asia rainfall simulations to cumulus and air-sea flux parameterizations in RegCM4. Climate Res 69:59-77. https://doi.org/10.3354/ cr01386

Kain JS, Fritsch JM (1993) Convective parameterization for mesoscale models: the Kain-Fritsch scheme. In: Emanuel KA, Raymond DJ (eds) The representation of cumulus convection in numerical models. Meteorological Monographs. American Meteorological Society, Boston, pp 165-170. https://doi.org/10. 1007/978-1-935704-13-3_16

Kang S, Im ES, Eltahir EAB (2018) Future climate change enhances rainfall seasonality in a regional model of western Maritime Continent. Climate Dynam 52:747-764. https://doi.org/10.1007/s00382-018-4164-9

Kieu-Thi X, Vu-Thanh H, Nguyen-Minh T, LE D, Nguyen-Manh Linh TI, Sasaki H, Kitoh A (2016) Rainfall and tropical cyclone activity over Vietnam simulated and projected by the Non-Hydrostatic Regional Climate Model - NHRCM. J Meteor Soc Japan 94:135-150. https://doi.org/10.2151/jmsj.2015-057

Kubota T, Shige S, Hashizume H, Aonashi K, Takahashi N, Seto S, Hirose M, Takayabu YN, Nakagawa K, Iwanami K, Ushio T, Kachi M, Okamoto K (2007) Global precipitation map using satellite-borne microwave radiometers by the GSMaP Project: production and validation. IEEE Trans Geosci Remote Sens 45(7):2259-2275. https://doi.org/10.1109/tgrs.2007.895337

Lee MH, Im ES, Bae DH (2019) Impact of the spatial variability of daily precipitation on hydrological projections: a comparison of GCM- and RCMdriven cases in the Han River basin, Korea. Hydrol Process 33(16):2240-2257. https://doi.org/10.1002/hyp.13469

Marhaento H, Booij MJ, Hoekstra AY (2018) Hydrological response to future landuse change and climate change in a tropical catchment. Hydrol Sci J 63(9): 1368-1385. https://doi.org/10.1080/02626667.2018.1511054

Mizuta R, Yoshimura H, Murakami H, Matsueda M, Endo H, Ose T, Kamiguchi K, Hosaka M, Sugi M, Yukimoto S, Kusunoki S, Kitoh A (2012) Climate simulations using MRI-AGCM3.2 with 20-km grid. J Meteor Soc Japan 90:233258. https://doi.org/10.2151/jmsj.2012-A12

Mohamoud YM (2008) Prediction of daily flow duration curves and streamflow for ungauged catchments using regional flow duration curves. Hydrol Sci J 53(4):706-724. https://doi.org/10.1623/hysj.53.4.706

Moriasi DN, Arnold JG, Van Liew MW, Bingner RL, Harmel RD, Veith TL (2007) Model evaluation guidelines for systematic quantification of accuracy in watershed simulations. Trans ASABE 50(3):885-900. https://doi.org/10.13031/ 2013.23153

Muis S, Güneralp B, Jongman B, Aerts JCJH, Ward PJ (2015) Flood risk and adaptation strategies under climate change and urban expansion: a probabilistic analysis using global data. Sci Total Environ 538:445-457. https://doi.org/10.1016/.scitotenv.2015.08.068

Neale R, Slingo J (2003) The maritime continent and its role in the global climate: a GCM study. J Climate 16:834-848. https://doi.org/10.1175/15200442(2003)016<0834:TMCAIR>2.0.CO:2

Nodzu Ml, Matsumoto J, Trinh-Tuan L, Ngo-Duc T (2019) Precipitation estimation performance by Global Satellite Mapping and its dependence on wind over northern Vietnam. Prog Earth Planet Sci 6:58. https://doi.org/10.1186/s40645019-0296-8

Popp A, Calvin K, Fujimori S, Havlik P, Humpenöder F, Stehfest E, Bodirsky BL, Dietrich JP, Doelmann JC, Gusti M, Hasegawa T, Kyle P, Obersteiner M, Tabeau A, Takahashi K, Valin H, Waldhoff S, Weindl I, Wise M, Kriegler E, Lotze-Campen H, Fricko O, Riahi K, Dv V (2017) Land-use futures in the shared socio-economic pathways. Glob Environ Chang 42:331-345. https:// doi.org/10.1016/j.gloenvcha.2016.10.002

Ramage CS (1968) Role of a tropical "maritime continent" in the atmospheric circulation. Mon Weather Rev 96(6):365-370. https://doi.org/10.1175/15200493(1968)096<0365:ROATMC > 2.0.CO;2

Rashid HA, Hirst AC (2017) Mechanisms of improved rainfall simulation over the Maritime Continent due to increased horizontal resolution in an AGCM. Climate Dynam 49:1747-1764. https://doi.org/10.1007/s00382-016-3413-z

Ratna SB, Ratnam JV, Behera SK, Tangang FT, Yamagata T (2017) Validation of the WRF regional climate model over the subregions of Southeast Asia: climatology and interannual variability. Climate Res 71:263-280. https://doi. org/10.3354/cr-1445

Saito K, Fujita T, Yamada Y, Ishida J, Kumagai Y, Aranami K, Ohmori S, Nagasawa R, Kumagai S, Muroi C, Kato T, Eito H, Yamazaki Y (2006) The operational JMA nonhydrostatic mesoscale model. Mon Weather Rev 134:1266-1298. https:// doi.org/10.1175/MWR3120.1

Sasaki H, Kurihara K, Takayabu I, Uchiyama T (2008) Preliminary experiments of reproducing the present climate using the Non-hydrostatic Regional Climate Model. SOLA 4:25-28. https://doi.org/10.2151/sola.2011-044

Sayama T, Ozawa G, Kawakami T, Nabesaka S, Fukami K (2012) Rainfall-RunoffInundation analysis of the 2010 Pakistan flood in the Kabul River Basin. Hydrol Sci J 57(2):298-312. https://doi.org/10.1080/02626667.2011.644245

Sayama T, Tatebe Y, Iwami Y, Tanaka S (2015) Hydrologic sensitivity of flood runoff and inundation: 2011 Thailand floods in the Chao Phraya River basin. Nat Hazards Earth Syst Sci 15:1617-1630. https://doi.org/10.5194/nhess-15$1617-2015$

Schiemann R, Demory ME, Mizielinski MS, Roberts MJ, Shaffrey LC, Strachan J, Vidale PL (2014) The sensitivity of the tropical circulation and maritime continent rainfall to climate model resolution. Climate Dynam 42:2455-2468. https://doi.org/10.1007/s00382-013-1997-0

Shige S, Kida S, Ashiwake H, Kubota T, Aonashi K (2013) Improvement of TMI rain retrievals in mountainous areas. J Appl Meteor Climatol 52:242-254. https:// doi.org/10.1175/jamc-d-12-074.1

Shige S, Kummerow CD (2016) Precipitation-top heights of heavy orographic rainfall in the Asian monsoon region. J Atmos Sci 73:3009-3024. https://doi. org/10.1175/JAS-D-15-0271.1

Shimada U, Kazumasa A (2017) Tropical cyclone intensity change and axisymmetricity deduced from GSMaP. Mon Weather Rev 145:1003-1017. https://doi.org/10.1175/MWR-D-16-0244.1

Stocker TF, Qin D, Plattner GK, Alexander LV, Allen SK, Bindoff NL, Bréon FM, Church JA, Cubasch U, Emori S, Forster P, Friedlingstein P, Gillett N, Gregory $J M$, Hartmann DL, Jansen E, Kirtman B, Knutti R, Krishna KK, Lemke P, Marotzke J, Masson-Delmotte V, Meehl GA, Mokhov II, Piao S, Ramaswamy V, Randall D, Rhein M, Rojas M, Sabine C, Shindell D, Talley LD, Vaughan DG, Xie S-P (2013) Technical Summary. In: Stocker TF, Qin D, Plattner G-K, Tignor MMB, Allen SK, Boschung J, Nauels A, Xia Y, Bex V, Midgley PM (eds) Climate change 2013: the physical science basis. Contribution of Working Group I to the Fifth Assessment Report of the Intergovernmental Panel on Climate Change. Cambridge University Press, Cambridge and New York

Takahashi H, Usup A, Hayasaka H, Limin SH (2003) Estimation of ground water level in a peat swamp forest as an Index of peat/forest fire. In: Osaki $\mathrm{M}$, Iwakuma T, Kohyama T, Hatano R, Yonebayashi K, Tachibana H, Takahashi H, Shinano T, Higashi S, Simbolon H, Tuah SJ, Wijaya H, Limin SH (eds) Proceeding of the International Symposium of Land Management and Biodiversity in Southeast Asia, Bali, 2002

Teutschbein C, Seibert J (2012) Bias correction of regional climate model simulations for hydrological climate-change impact studies: review and evaluation of different methods. J Hydrol 456-457:12-29. https://doi.org/10. 1016/j.jhydrol.2012.05.052

Ulate M, Dudhia J, Zhang C (2014) Sensitivity of the water cycle over the Indian Ocean and Maritime Continent to parameterized physics in a regional model. J Adv Model Earth Syst 6(4):1095-1120. https://doi.org/10.1002/ 2014MS000313

Wang L, Chen W (2014) Equiratio cumulative distribution function matching as an improvement to the equidistant approach in bias correction of rainfall. Atmos Sci Lett 15:1-6. https://doi.org/10.1002/as/2.454

Weedon GP, Balsamo G, Bellouin N, Gomes S, Best MJ, Viterbo P (2014) The WFDEI meteorological forcing data set: WATCH Forcing Data methodology applied to ERA-Interim reanalysis data. Water Resour Res 50:7505-7514. https://doi.org/10.1002/2014WR015638

Yamamoto EMS, Sayama T, Apip YK (2020) Comparison of runoff generation methods for land use impact assessment using the SWAT model in humid tropics. Hydrol Res Lett 14(2):81-88

Yamamoto K, Sayama T, Apip TK (2019) Applicability of Rainfall-Runoff-Inundation model in a humid tropical river basin. J Japan Soc Civil Eng 75(2):I_253-I_258 (in Japanese)

Yamamoto MK, Shige S (2015) Implementation of an orographic/nonorographic rainfall classification scheme in the GSMaP algorithm for microwave radiometers. Atmos Res 163:36-47. https://doi.org/10.1016/j.atmosres.2014.07. 024

\section{Publisher's Note}

Springer Nature remains neutral with regard to jurisdictional claims in published maps and institutional affiliations. 